\title{
TEACHING ENGLISH LANGUAGE IN HETEROGENEOUS CLASSROOMS
}

\author{
CWahedi N., ORCID: 0000-0002-3553-290X, Uzbekistan State University of World Languages, \\ Tashkent, Uzbekistan, nargizawahedi@gmail.com
}

\section{ОБУЧЕНИЕ АНГЛИЙСКОМУ ЯЗЫКУ В ГЕТЕРОГЕННЫХ КЛАССАХ}

\author{
СВахеди Н. Г., ORCID: 0000-0002-3553-290Х, Узбекский государственный университет \\ мировых языков, г. Ташкент, Узбекистан, nargizawahedi@gmail.com
}

Abstract. The article aims to provide a thorough insight into the teaching context of heterogeneous classes in line with identifying their most distinctive features, certain elements that form differences that most often EFL teachers note challenging. Based on needs evaluation it is possible to create a successful learning environment where efficient lesson plan assisted by credible techniques will be united around a single concept of a competent teacher ready to espouse the students who need support.

Аннотащия. Целью данной статьи является подробное описание гетерогенных классов в учебном контексте в соответствии с определением их наиболее отличительных черт, и определенных элементов, образующие различия, которые чаще всего отмечают учителя английского языка. На основе оценки потребностей можно создать успешную учебную среду, в которой эффективный план урока с помощью надежных педагогических техник будет объединен вокруг единого понятия профессионального учителя, готового помочь тем ученикам, которые нуждаются в поддержке.

Keywords: heterogeneous class, multi-level class, EFL, receptive skills, productive skills.

Ключевые слова: гетерогенный класс, многоуровневый класс, английский как иностранный, рецептивные навыки, продуктивные навыки.

The English language has been recognized as a lingua franca in recent years that created a growing demand to become competent in it all over the world. Numerous students flooded the EFL classrooms willing to master the global language, which allows them to access various personal and career opportunities. As a result, nowadays, more and more teachers in the EFL context struggle with time-management, maintaining class discipline and attempting to attend to the heterogeneity of learner needs all at once. A heterogeneous class could be defined as "one that has different kinds of learners in it"[1]. Since students of EFL classrooms more than often have various levels of language proficiency, every class can be considered multilevel to some degree [1]. By nature, all classes should be regarded as heterogeneous on the grounds of the assumption that there does not exist any single-level grouping of students. In reality, in any class all learners are unique since language learners move at different rates, some of them are at ease with receptive skills, such as, listening and understanding written material, the others are good at productive skills, e.g., interpersonal communication. 
It is widely acknowledged that every single student is unique and not identical compared to others. Various factors characterize learners. According to P. Ur, several aspects contribute to the formation of a heterogeneous class, namely, "language knowledge, cultural background, attitude to the language, mother tongue, intelligence, world knowledge, learning experiences, knowledge of other languages..."[1]. In line with the aforementioned features, we can also outline the following factors that strongly influence the learner's language performance, these are mentality, surrounding environment, access to resources, and availability to have a free time to learn. For example, the mentality and cultural background of a learner can seriously affect their perception of the teacher's role and the way they conduct a class. If a learner accustomed to a teacher-centred, traditional method of learning and for the first time, he is placed in a classroom with an instructor who uses primarily student-centred methods, the learner may be discouraged assuming unfamiliar ways of conducting the class as something ineffective and strange. Likewise, Julie Mathews-Aydinli and Regina Van Horne presume that the level of literacy and education in the native language, as well as age and social status, make a huge distinction in heterogeneous classes as well [2].

From the perspective of teaching context, the diversity in student backgrounds results in both advantageous and disadvantageous sides of heterogeneous classes. There are many problematic issues when it comes to teaching large and at the same mixed-level classes. First, the domination of proficient and self-confident students who always tend to answer every single question without giving the turn to their peers, interrupting someone who is already speaking but at a slower pace, pressing at someone who needs a moment for recalling a necessary word, speaking without raising their hand or without waiting their turn. Secondly, the passive behavioral patterns of some beginner learners. There are students reluctant to speak as they are afraid to make mistakes or they think that they are not yet ready to express themselves in the target language due to apparent problems e.g., with pronunciation. Thirdly, lack of flexibility in language course books. In other words, the absence of suitable and multilevel course books those teachers can use universally with a set of optional tasks and adjustable activities. In most cases, tasks prepared by course instructors are easy for the majority of students in class or vice versa, they are rather difficult [3]. Consequently, this situation leads to fading away learners' interest, which successively causes boredom and indifference. Lastly, discipline problems arise as in large, heterogeneous classes teachers feel as they lose their authority.

Nonetheless, multi-level classes are hard to teach and instruct, some positive features contribute to effective teaching of the target language. It is known that a teacher can organize class activities within four modes of student division: whole-class interaction, group work, team project, pair work [2]. Therefore, whilst instructors of relatively small classes are limited to organize different activities that involve larger numbers of participants, teachers of heterogeneous classes can vary different modes and group their students following their needs. Besides, heterogeneous classes are "a much richer pool of human resources" [Ur, 305], and the outcome of such varied interaction will be more interesting, abundant in innovative ideas and new insights that could be used efficiently as content-based interaction.

Another idea is the role of a teacher in heterogeneous classes. As the teacher experiences time limitations to control all the students, the students themselves take a responsibility to learn in cooperation. According to M. Rogers, there are three categories of learners: high-level, at-level, and low-level learners. Above-level students attempt to explain the instructions or the grammar rule to a below-level student. Two at-level students can mutually help each other to work out a solution posed by the instructor. Finally, from the position of a teacher, large, heterogeneous classes are demanding to train, require extra time and preparation; however, they foster teacher's creativity, flexibility, tolerance and resistance to stress [4]. 
In the face of many obvious constraints in heterogeneous classes, it is apparent that these classes need to be taught in a different way than homogeneous ones. Some effective strategies could be employed in the teaching practice of heterogeneous classes. To begin with, needs assessment is of paramount importance. Instructors collect valuable insights about what students expect from the course and what they want to learn. One way is to conduct a one-to-one interview with students or organize a class discussion. The initial needs assessment will help a teacher to determine common topics of interest, shared ideas and general background; whilst regular ongoing needs assessment throughout the course will be beneficial for the teacher to navigate through the course and adjust the material accordingly.

Another notable idea is that from the first class, a teacher should indicate an order of transitions from one task to another and incorporate some rules to manage the class, such as turntaking while speaking. Students learn gradually how to follow class procedures; the more they get accustomed to repetitive patterns, the less time teacher needs to re-explain instructions, and that can eliminate the downtime as the course progresses.

Next, concerning material design, it is a good strategy to select a wide range of topics to introduce to the class, teachers can create various activities based on interesting topics, which provoke interest and defeat boredom.

In order to phase out passive participation teachers can use compulsory plus optional instructions offered by P. Ur. A teacher urges students to do a certain number of exercises and the rest is optional; the supplementary material is for the above-level students who wish to work more, in fact, they are encouraged to do the entire set of exercises. One more variation that could be added is leveling the tasks. One exercise is designed to elicit various output, it can be a limited response task with closed-ended questions but also free output in the form of reflection with open-ended questions. In this activity, low-level learners work with closed-ended questions while at-level and high-level learners engage with open-ended variations. Another option to diversify this strategy is to prepare three variations of one worksheet with different levels of difficulty. All three variations are based on the covered material. Students can independently choose easy, medium or advanced variation. This allows the teacher to observe students' self-evaluation concerning their progress as well. Then, the teacher may use different grouping strategies, e.g., he can place similar-ability students together so that they can counsel with each other, find the correct answer and compare it. This strategy fosters cooperation among students and a positive class climate.

Another forceful strategy on how to gain quick insight into students' grasp of explanation or provided input is to use a technique called "Fist to Five". A teacher asks students to evaluate their understanding of the covered input based on a scale from one to five and show it by raising their hands indicating understanding by fingers. If a student shows five fingers that means he completely understands the covered material, but if he shows a fist that means he is completely lost; two, three, and four fingers correspond with average evaluation of self-perception. By doing so, the teacher can assess general class comprehension and students who require extra clarification. "Fist-to-Five" technique is a two-fold utile; teachers can use it additionally as a means to maintain discipline in a class. When students become noisy and distracted, a teacher raises his/her fist and counts to five, within this timeframe, students fix their attention to the teacher and are ready to engage in a new activity. Furthermore, memorizing students' names and addressing them personally is also a helpful technique to control class management.

Overall, as no learner is similar most language classes are heterogeneous that are challenging to teach and properly manage. Although these classes possess certain negative characteristics, there exist many highly efficient techniques to prevent anticipated negative patterns. The success is guaranteed, when thoroughly pre-planned EFL classes are conducted by competent teachers, with a 
positive class atmosphere where students thrive to absorb meaningful input, along with a favorable attitude toward language learning.

\section{References:}

1. Ur, P. A (1996). Course in Language Teaching: Practice to Theory. Cambridge: Cambridge University Press, 375.

2. Hedge, T. (2000). Teaching and Learning in the Language Classroom. Oxford: Oxford University Press, 464.

3. Mathews-Aydinli, J., \& Van Horne, R. (2019). Promoting the success of multilevel ESL classes: What teachers and administrators can do. Washington, DC: Center for Applied Linguistics, Retrieved November 15.

4. Roberts, M. (2019). Teaching in the multilevel classroom. New York: Pearson Education, 2007. Retrieved December 10.

\section{Список литературы:}

1. Ur P. A Course in Language Teaching: Practice to Theory. Cambridge: Cambridge University Press, 1996. 375 p.

2. Hedge, T. Teaching and Learning in the Language Classroom. Oxford: Oxford University Press, 2000. 464 p.

3. Mathews-Aydinli, J., \& Van Horne, R. Promoting the success of multilevel ESL classes: What teachers and administrators can do. Washington, DC: Center for Applied Linguistics, 2006. Retrieved November 15, 2019.

4. Roberts, M. Teaching in the multilevel classroom. New York: Pearson Education, 2007. Retrieved December 10, 2019.

Работа поступила

в редакцию 14.01.2020 2.
Принята к публикащчии

19.01.2020 2.

Ссылка для цүитирования:

Wahedi N. Teaching English Language in Heterogeneous Classrooms // Бюллетень науки и практики. 2020. Т. 6. №2. С. 293-296. https://doi.org/10.33619/2414-2948/51/34

Cite as (APA):

Wahedi, N. (2020). Teaching English Language in Heterogeneous Classrooms. Bulletin of Science and Practice, 6(2), 293-296. https://doi.org/10.33619/2414-2948/51/34 